\title{
Fatty Acids of Sestonic Lipid Classes as a Tool to Study Nutrition Spectra of Rotifers and Ciliates in a Siberian Eutrophic Reservoir
}

\author{
Olesya N. Makhutova* and Elena B. Khromechek \\ Institute of Biophysics of Siberian Branch of Russian Academy of Sciences, \\ Akademgorodok, Krasnoyarsk, 660036 Russia $^{1}$
}

Received 1.09.2007, received in revised form 1.12.2007, accepted 15.01.2008

Fatty acid composition of triacylglycerols (TAG) and polar lipids (PL) of seston from the Siberian Reservoir Bugach was analyzed to reveal the spectra of nutrition of micro- and mesozooplankton (protozoa and rotifers). The seasonal changes of micro- and mesozooplankton nutrition were observed. Bacteria comprised relatively constant part in feeding protozoa and rotifers during the whole vegetation season. The maximum consumption of higher plants detritus occurred at the beginning of August. Phytoplankton was consumed more intensively in spring during the rapid growth of diatoms (Stephanodiscus sp.) and from the middle to the end of June when cyanobacteria (Anabaena flos-aquae, Aphanizomenon flos-aquae, Planktothrix agardhii), dynophytes (Peridinium sp.) euglenas (Euglena proxima) and diatoms (Stephanodiscus sp.) were dominated in Bugach Reservoir. The dominant species of protozoa differed in their nutrition spectra: Holophrya sp. was feeding on diatoms in spring and bacteria in the middle of summer; Tintinidium sp. was consuming diatoms and cyanobacteria; Nassula picta was feeding on cyanobacteria.

Keywords: spectra of nutrition, fatty acids, TAG, PL, seston, bacterioplankton, phytoplankton, microand mesozooplankton, multivariate analysis.

\begin{tabular}{|c|c|}
\hline Introduction & specific ingestion of food particles by some rotifer \\
\hline Nutrition of small-size & and small crustacean species (DeMott, 1986, \\
\hline nhabited freshwater ecosystems (micro- and & 1995). However, the visual gut content analysis \\
\hline mesozooplankton) is almost unknown, while & \\
\hline these organisms are one of the most important & \\
\hline components of trophic webs in various reservoirs. & \\
\hline Micro- and mesozooplankton takes a vital part & $\begin{array}{l}\text { SS et } \\
\text { rned }\end{array}$ \\
\hline rule, nutrition of aquatic animals is studied by & wing rather then \\
\hline visual microscopic analysis of their gut contents & assimilation (Thouvenot, \\
\hline $\begin{array}{l}\text { (Gutelmakher, 1986; DeMott, 1986, 1995; Bern, } \\
\text { 1990) As a result number of authors has proved }\end{array}$ & $\begin{array}{l}\text { years, different chemical makers appeared to be } \\
\text { of use in studies of nutrition of microzooplankton. }\end{array}$ \\
\hline
\end{tabular}

\footnotetext{
Corresponding author E-mail address: makhutova@ibp.krasn.ru

c) Siberian Federal University. All rights reserved
} 
For instance, C. Joaquim-Justo with coauthors (2004) have estimated feeding planktonic rotifers on ciliates using fluorescent microparticles. However, this method has shortcomings: shortterm observation and impossibility to apply the method for field populations.

Along with the mentioned methods, biochemical analysis of fatty acid (FA) composition is widely used at present which allows to trace trophic interactions between hydrobionts and to reveal food assimilation (Claustre et al., 1988/1989; Ederington et al., 1995; Gladyshev et al., 1999; Sushchik et al., 2003b). The significance of FA as markers of particular groups of hydrobionts is resulted from the wellknown taxonomic peculiarities of FA composition. An important aspect of fatty acids as trophic markers is that the fatty acid composition of an animal represents the time-integrated dietary intake (Napolitano, 1999).

Total FA composition of seston is formed by FA of all of its components: bacterioplankton, phytoplankton, zooplankton and detritus organic matter. FA composition of the major lipid classes, namely triacylglycerols and polar lipids, allows to reveal specific groups of organisms and trophic interactions in ecosystems. All hydrobionts contain PL, which fatty acid composition is formed mostly by de novo biosynthesis (Napolitano and Ackman, 1989). Phospholipids (the main polar lipids in organisms), which have the highest content of PUFA, are primarily structural and fundamentally important for transport across membranes and enzymatic reactions in the cell. The composition of phospholipids is subjected to some, but not complete, genetic control by the fact that the enzymes that form phospholipids select for polyunsaturated fatty acids (Olsen, 1999). As a result, fatty acid profile of PL varied little between the starvation and feeding periods of a copepod, while the fatty acids in its storage lipids reflected those of food sources (Bourdier and Amblard, 1989). In general, the zooplankton TAG characterized by dominance of dietary fatty acids (Olsen, 1999) and closely relates relates its food composition (Desvilettes et al., 1997).

Bacteria and cyanobacteria don't contain TAG (Shaw, 1974; Desvilettes et al., 1997). Many species of plankton algae store energy as carbohydrates (Olsen, 1999). Microalgae can only synthesize a significant portion of TAG in unfavorable conditions (Cobelas, Lechado, 1989; Brown et al., 1996; Olsen, 1999; Tonon et al., 2002).

Intensive accumulation of TAG is typical for animals, therefore the main part of TAG of lower size seston is likely contained in biomass of microand mesozooplankton, i.e., protozoa, rotifers and small crustaceans. Thus, it is very perspective to use TAG FA composition of natural seston for estimation of the sources of assimilated food of the small-size hydrobionts.

In this study, fatty acid composition of TAG and PL of the seston from an eutrophic reservoir was studied to determine the main food sources and seasonal changes in nutrition spectra of species of rotifers and ciliates from an eutrophic reservoir.

\section{Investigated Area, Materials and Methods}

Bugach Reservoir is situated near Krasnoyarsk (Siberia, Russia, $56^{\circ} 05^{\prime} \mathrm{N}, 92^{\circ} 40^{\prime} \mathrm{E}$ ) in a steppe and was formed by damming the Bugach River. Its surface area is $0.32 \mathrm{~km}^{2}$ and maximum depth is seven meters. The Reservoir was sampled weekly from May to September 2001 from a site near the middle. Samples were taken with an 8-L sampler and were pooled from depths 1-3 m. Detailed description of the Reservoir is given elsewhere (Gladyshev et al., 2001; Makhutova et al., 2003; Suschik et al., 2003a, 2004). 
To determine the total number of bacteria, 1 $\mathrm{mL}$ of each sample was preserved with ethanol ( $10 \%$ final concentration). Cells were immediately stained with fluorescamine (Sigma, USA) and collected onto $0.2-\mu \mathrm{m}$ poresized membrane filter (Chimifil, Estonia) prestained with Sudan Black B (Chemapol, Czechoslovakia) ethanol solution. Counts were carried out using epifluorescence microscopy.

Phytoplankton samples of $0.1 \mathrm{~L}$ volume were filtered through 'Vladipor' filters (Mytischi, Russia) (pore size, 0.75-0.85 $\mu \mathrm{m}$ ). Microalgae were counted and identified under a microscope. To calculate biovolume and wet biomass of algae, they were equated to appropriate geometrical shapes and relevant sizes were measured using an ocular micrometer (LOMO, Russia).

Zooplankton samples of $33.6 \mathrm{~L}$ volume were filtered through the 0.08 -mm plankton net. Then, the samples were fixed with $10 \%$ formalin. Zooplankton were counted and measured under a microscope. Length was converted to wet weight using conventional species coefficients (Balushkina and Vinberg, 1979).

Ciliates were counted both alive and fixed with Lugol's solution (1\% final concentration). The For counting alive individuals a sample of $1 \mathrm{~L}$ of volume was taken, then allowed to settle for 24 hours and poured. Ten replicate aliquots were taken of $25 \mu \mathrm{L}$ and large live ciliates were counted in the Bogorov chamber in the aliquots. Small-size species were counted by the drop method in the $25-\mu \mathrm{L}$ samples; 20 replicates were used. Fixed samples were treated in the FuchsRosenthal chamber. Counts were made using an MBI-11 light microscope and an Axioskop 40 fluorescence microscope (Carl Zeiss). Small ciliates (less than $40 \mu \mathrm{m}$ in length) were counted and identified at $\times 400-600$ magnification. To count large species the entire chamber was surveyed at x100 magnification. To calculate the average wet weight, 50 individuals of each species were measured. Biovolumes of ciliates were estimated according to Foissner and Berger (1996). Ciliate species identification was done in accordance with Kahl's classification.

Seston was collected from the integral water samples by vacuum filtration through membrane filters 'Vladipor No. 8' (pore size 0.75-0.85 $\mu \mathrm{m}$ ) precovered with a layer of $\mathrm{BaSO}_{4}$ to facilitate the separation of residue. Surface of the filter was carefully examined and individulas of macrozooplankton species (daphnids, copepods and etc.) were eliminated. The filters then were dried at $35^{\circ} \mathrm{C}$ during $30 \mathrm{~min}$, the residue was separated from filters, placed into chloroform/methanol/ $(2: 1, v / v)$ and frozen at $-20^{\circ} \mathrm{C}$ until further analysis.

Lipids were extracted by homogenizing of the samples of seston in chloroform/methanol mixture $(2: 1, \mathrm{v} / \mathrm{v})$ and the residues were allowed to precipitate while the extracts were cooled (Bligh and Dyer, 1959). Then the extracts were dried by passing through anhydrous $\mathrm{Na}_{2} \mathrm{SO}_{4}$ and roto-evaporated at $35^{\circ} \mathrm{C}$. A part of the lipid extract was subjected to acidic methanolysis as described previously (Gladyshev et al., 2000). Another part of the extract was separated on a TLC $6 \times 6 \mathrm{~cm}$ microplate with solvent system for neutral lipids: hexane/ diethyl ether/ acetic acid (85:15:1, v/v/v). Lipid spots were identified by comparing their $R_{f}$ with those of standards (Sigma, Serva) (Kalachova et al., 2001). Silica gel, containing triacylglycerols and polar lipids was scraped from the plates and placed into $3 \mathrm{ml}$ of diethyl ether (TAG) or of diethyl ether/ ethanol $(1: 1, \mathrm{v} / \mathrm{v})$ (PL) for 20 min. Then, to remove the silica gel, the solutions were filtered through a glassfiber GF/C filter and fixed volumes $(20 \mu \mathrm{l})$ of internal standard (19:0) solution of $0.5 \mathrm{mg} / \mathrm{ml}$ were added. After solvent evaporation, the acidic methanolysis was carried out to prepare fatty acid methyl esters (FAME) of the FA of these two lipid classes. Further fatty acid analysis is described in detail elsewhere 
(Gladyshev et al., 2000). Briefly, FAMEs were analyzed on a gas chromatograph equipped with a mass spectrometer detector (GCD Plus; HewlettPackard, La Jolla, CA, U.S.A.) with a $30 \mathrm{~m}$ long $\times 0.32 \mathrm{~mm}$ internal diameter capillary column HPFFAP. The column temperature programming was as follows: from 100 to $190^{\circ} \mathrm{C}$ at $3^{\circ} \mathrm{C} \mathrm{min}^{-1}, 5 \mathrm{~min}$ isothermally, to $230^{\circ} \mathrm{C}$ at $10^{\circ} \mathrm{C} \mathrm{min}^{-1}$, and $20 \mathrm{~min}$ isothermally. Other instrumental conditions were as described elsewhere (Gladyshev et al., 2000). Peaks of FAMEs were identified by their mass spectra similar to those in the database (HewlettPackard) and to those of available authentic standards (Sigma, St Louis, MI, USA.). Detailed de-scriptions of determination of position of double bonds in fatty acids are given elsewhere (Sushchik et al., 2003b, 2004).

Statistical analyses, correspondence analysis (CA), canonical correlation analysis (CCA) and correlation analysis were carried out conventionally (Jeffers, 1981) using STATISTICA software, version 6.0 (StatSoft Inc., Tulsa, OK, USA).

\section{Results}

The dynamics of the major plankton groups comprising seston (bacterioplankton, phytoplankton, protozoans, rotifers, and small crustaceans) are shown in Fig. 1.
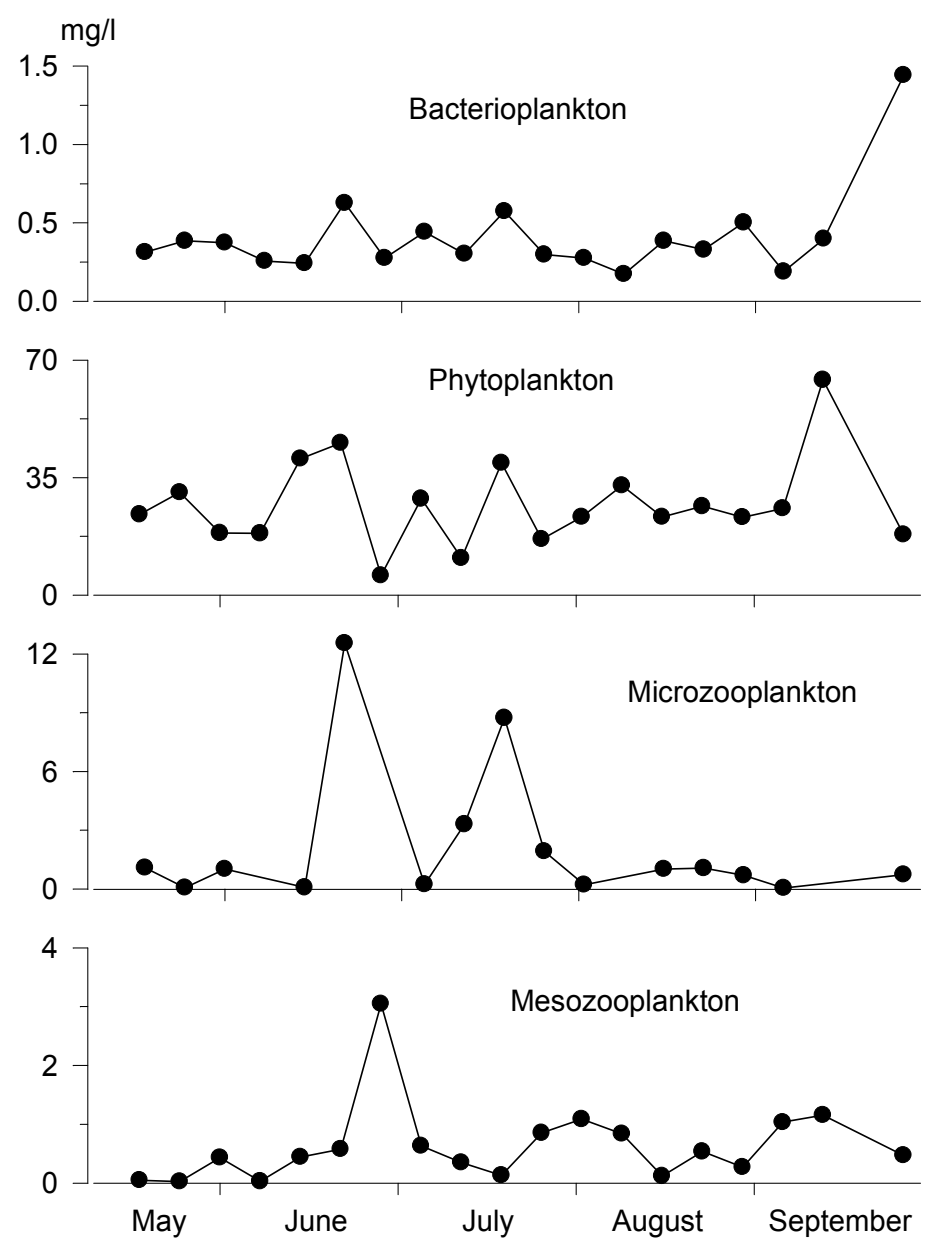

Fig. 1. Seasonal dynamics of biomass of bacterioplankton, phytoplankton, microzooplankton and mesozooplankton (mg/L) from Bugach Reservoir, 2001. 
Biomass of bacterioplankton ranged from 0.2 to $1.4 \mathrm{mg} / \mathrm{L}$, and the average value was $0.4 \mathrm{mg} / \mathrm{L}$. The biomass of phytoplankton changed markedly during the vegetation season and accounted for 5.9 to $64.1 \mathrm{mg} / \mathrm{L}$ with average of $27.2 \mathrm{mg} / \mathrm{L}$. The biomass of microzooplankton varied from 0.1 to $12.6 \mathrm{mg} / \mathrm{L}$ and was $2.2 \mathrm{mg} / \mathrm{L}$ in average. The biomass of mesozooplankton varied from 0.02 to $3.1 \mathrm{mg} / \mathrm{L}$, and the average value was $0.6 \mathrm{mg} / \mathrm{L}$ (Fig. 1).
Evidently, main part of both organic matter and fatty acids of PL in seston were formed by phytoplankton (Fig. 1). The correlation analysis of fatty acid percentages in PL presented as the cor-relation graph, revealed three groups of FA with similar seasonal dynamics and two individual FA (Fig. 2). Apparently, each group of acids originated from the one source. The first group consisted of long-chain saturated fatty acids, which are considered as markers of higher plants,
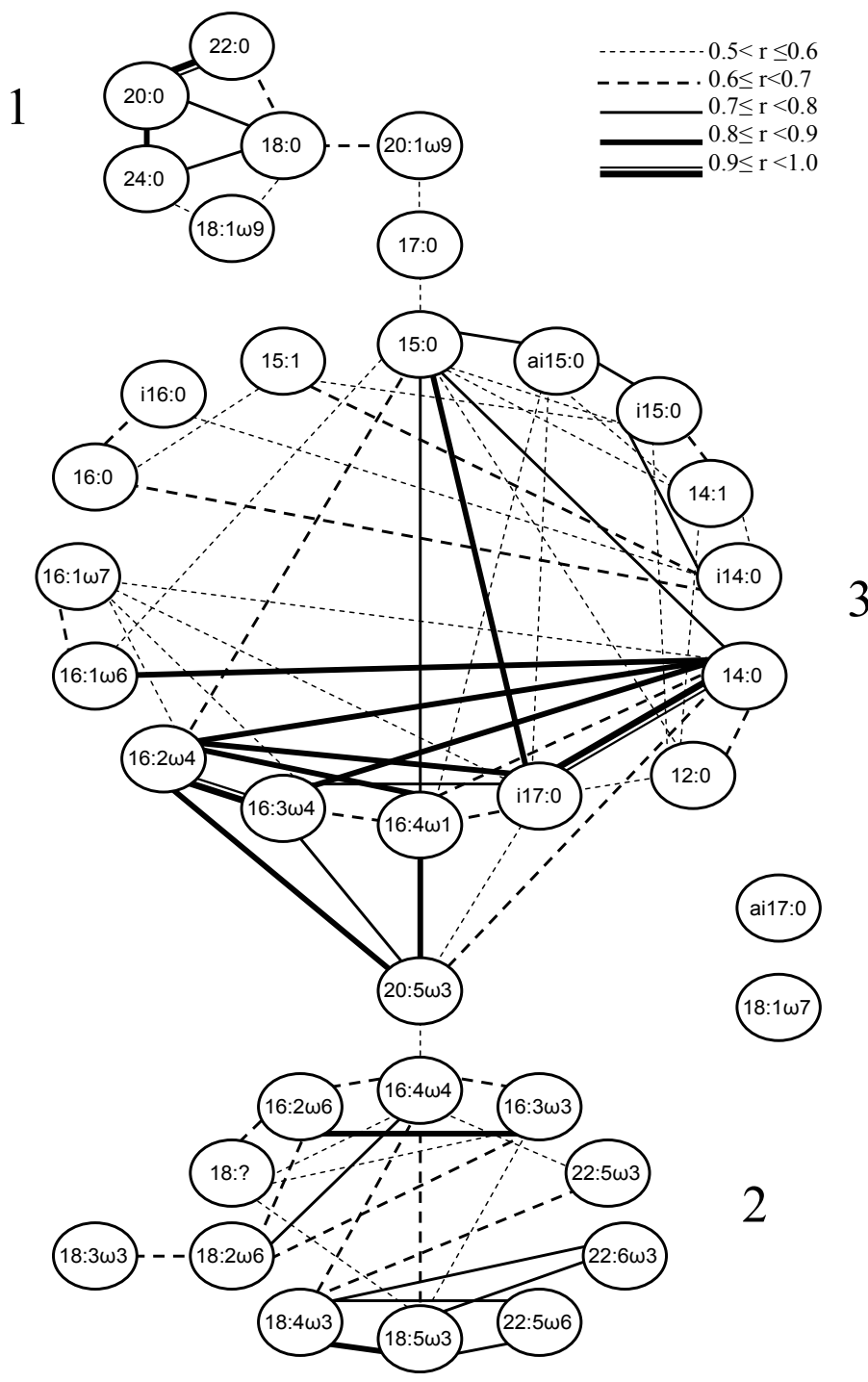

Fig. 2. Correlation graphs of fatty acids of PL (\% of total) in seston of Bugach Reservoir, May-September 2001: $\mathrm{r}$ - statistically significant correlation coefficients $(\mathrm{p}<0.05) .1-$ FA-markers of higher plants;

2 - FA-markers of cyanobacteria, green and dinophyte algae; 3 - FA-markers of bacteria and diatoms 
and two wide-spread acids, 18:0 and 18:169. The second group consisted of fatty acids, which are markers of Cyanophyta, Chlorophyta, and Dinophyta; and some markers of animals (22:5 $\omega 6$ и 22:5 13 ) (Fig. 2). The third group was formed by FA - markers of Bacillariophyta and bacteria (Fig. 2). Seasonal dynamics of two bacterial fatty acids, 18:1 $\omega 7$ and ai17:0, differed from other bacterial fatty acids that were included in the group 3 (Fig. $2,3)$. Seasonal dynamics of all groups of FA in PL are shown in Fig. 3.

To define specific FA-markers of individual species of phytoplankton we carried out the canonical correspondence analysis. The percentage of supposed FA-markers of algae (in PL of seston) on dates when some phytoplankton species were strongly dominant (more then 50\%) was represented in a two-dimensional space (Fig. 4). The first dimension explained $87.4 \%$ of inertia (of total Chi-square value) of the data set, and the second dimension reproduced $10.5 \%$. Chi-square values for both dimensions and the total Chi-square were significant $(\mathrm{P}<0.05)$. Biomass and dominant species composition of phytoplankton in Bugach Reservoir during the vegetation season are shown in Table 1. Three species of algae were constituted more then $50 \%$ (\% of total biomass): Stephanodiscus sp. at 16.05.2001 and 23.05.2001; Planktothrix agardhii (Gom.) Anagn et Kom. at 30.05.2001, 06.06.2001 and 26.09.2001; and Trachelomonas volvocina Ehr. at 12.09.2001. The first dimension (Fig. 4) showed large differences between three groups of species dominated in different periods of season: 1) Stephanodiscus sp. 16.05.2001 and 23.05.2001; 2) P. agardhii 30.05.2001 and 26.09.2001 and T. volvocina 12.09 .2001 ; 3) $P$. agardhii 06.06.2001. These positions of algal species in the first dimension were provided mostly by differences in following fatty acids: the first

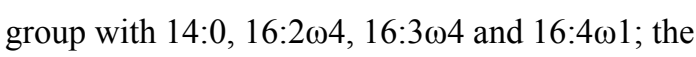

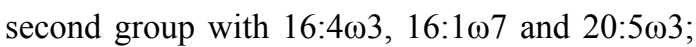

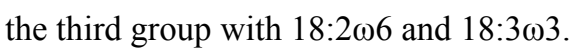

Since the second dimension explained only $10.5 \%$ of inertia that compare with error of FA and phytoplankton analyses, this dimension is not considered.

There were eighteen species of micro- and mesozooplankton dominated in Bugach Reservoir in 2001. They included five species of rotifers, i.e. Brachionus calyciflorus Pallas, Brachionus diversicornis Daday, species of Asplanchna (Asplanchna henrietta Langhans, Asplanchna girodi Guerne, Asplanchna brightwelli Gosse), and thirteen species of protozoa (Fig. 5).

We didn't find daphnids, Daphnia longispina O.F. Muller and Daphnia cucullata which were previously dominant species in Bugach (Sushchik et al., 2003a) during growth season of 2001. Several species of protozoa and rotifers, namely Tintinidium sp., Brachionus calyciflorus, Rimostrombidium humile Penard, Asplanchna genus and Coleps hirtus Nitzsch, occurred during relatively long periods or during almost all vegetation season (Fig. 5). Other species of microand mesozooplankton dominated occasionally (Fig. 5).

Assuming that fatty acids of TAG in seston samples are mostly originated from the biomass of micro- and mesozooplankton and closely related with their food sources, we make attempt to identify the food sources of protozoa and rotifers by analysis of correlation graph of fatty acids of sestonic TAG (Fig. 6).

The correlation analysis of FA percentages in TAG revealed four groups of acids and two separate FA with different seasonal dynamics (Fig. 6). The first group consists of long chain satu-rated fatty acids (the markers of plants) and 18:0. The second group consists of FA-markers of phytoplankton (cyanobacteria, green and dinophyte algae) and the third group contains bacterial fatty acids. The percentage of one more bacterial fatty acid 18:1 107 was characterized by specific dynamic (Fig. 6, 7). The fourth group was 

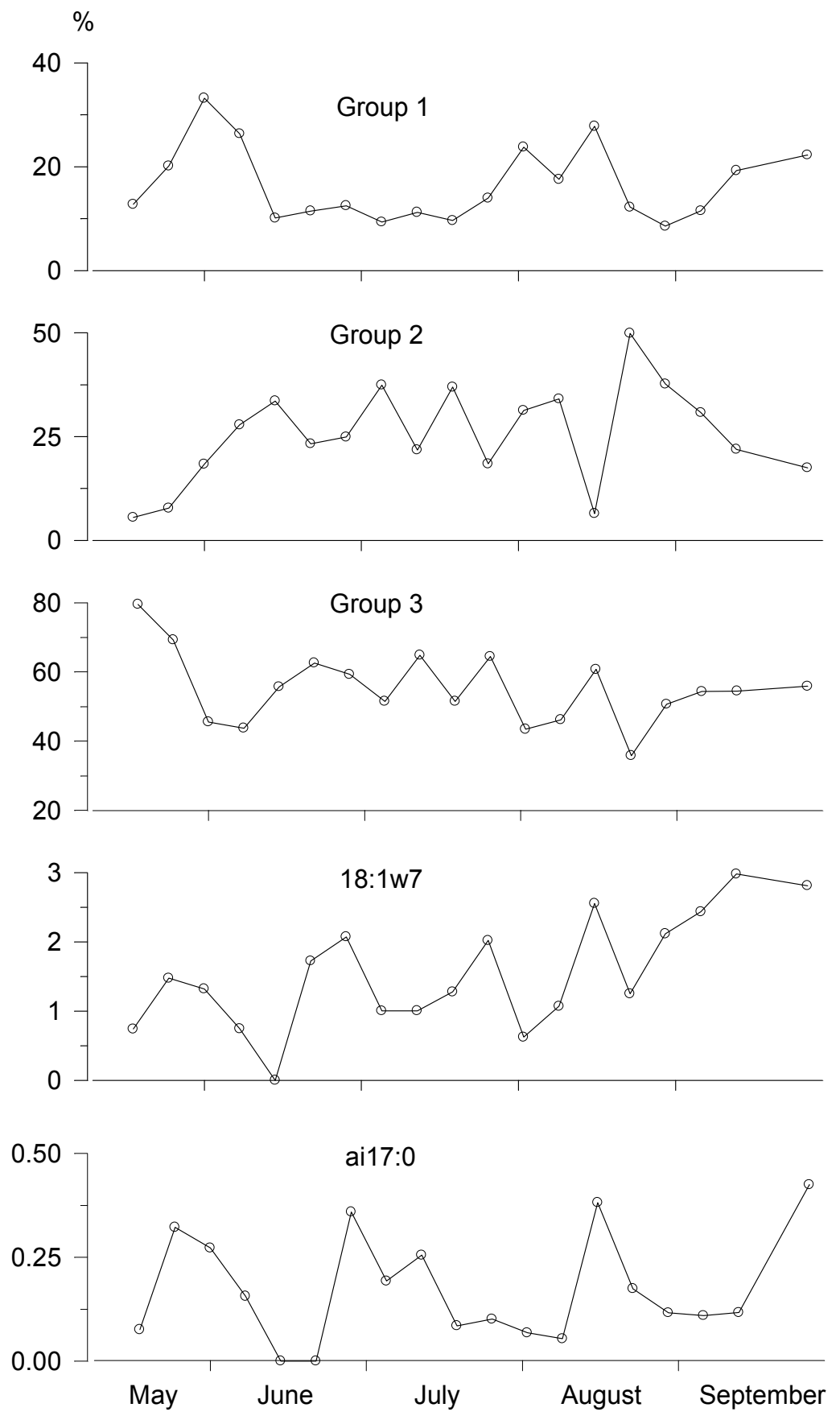

Fig. 3. Seasonal dynamics of FA groups and individual acids of PL (\% of total) showed in the correlation graph (see Fig. 2) for seston of Bugach Reservoir, 2001. Numeration of the groups corresponds to the that in Fig. 2 
Table 1. Biomass and dominant species composition of phytoplankton in Bugach Reservoir, 2001. Total biomass is $\mathrm{mg}$ of wet weight $\mathrm{L}^{-1}$

\begin{tabular}{|c|c|c|c|}
\hline $\begin{array}{l}\text { Date of } \\
\text { sampling }\end{array}$ & Dominant species & $\begin{array}{c}\text { Total biomass, } \\
\mathrm{mg} \mathrm{WW} \mathrm{L}^{-1}\end{array}$ & $\begin{array}{l}\% \text { of total } \\
\text { biomass }\end{array}$ \\
\hline \multirow{3}{*}{16.05 .01} & Stephanodiscus sp. & 22.781 & 94.64 \\
\hline & Aphanizomenon flos-aquae (L.) Ralfs & 0.424 & 1.76 \\
\hline & Euglena proxima Dang. & 0.206 & 0.86 \\
\hline \multirow[t]{3}{*}{23.05 .01} & Stephanodiscus sp & 22.969 & 74.95 \\
\hline & Planktothrix agardhii (Gom.) Anagn. et Kom. & 2.457 & 8.02 \\
\hline & Euglena proxima Dang. & 1.266 & 4.13 \\
\hline \multirow[t]{3}{*}{30.05 .01} & Planktothrix agardhii (Gom.) Anagn. et Kom. & 11.820 & 63.97 \\
\hline & Stephanodiscus sp. & 3.120 & 16.89 \\
\hline & Euglena proxima Dang. & 0.933 & 5.05 \\
\hline \multirow[t]{3}{*}{6.06 .01} & Planktothrix agardhii (Gom.) Anagn. et Kom. & 11.276 & 61.24 \\
\hline & Aphanizomenon flos-aquae (L.) Ralfs & 2.940 & 15.97 \\
\hline & Euglena proxima Dang. & 1.703 & 9.25 \\
\hline \multirow[t]{3}{*}{ 13.06.01 } & Planktothrix agardhii (Gom.) Anagn. et Kom. & 20.197 & 49.72 \\
\hline & Euglena proxima Dang. & 6.244 & 15.37 \\
\hline & Peridinium sp. Ehr. & 4.771 & 11.75 \\
\hline \multirow[t]{3}{*}{ 20.06.01 } & Peridinium sp. Ehr. & 17.320 & 38.19 \\
\hline & Euglena proxima Dang. & 7.679 & 16.93 \\
\hline & Anabaena flos-aquae (Lyngb.) Breb. & 5.371 & 11.84 \\
\hline \multirow[t]{3}{*}{ 27.06.01 } & Anabaena flos-aquae (Lyngb.) Breb. & 1.679 & 28.69 \\
\hline & Aphanizomenon flos-aquae (L.) Ralfs & 1.252 & 21.38 \\
\hline & Stephanodiscus sp. & 1.225 & 20.93 \\
\hline \multirow[t]{3}{*}{4.07 .01} & Anabaena flos-aquae (Lyngb.) Breb. & 12.174 & 42.4 \\
\hline & Aphanizomenon flos-aquae (L.) Ralfs & 4.372 & 15.23 \\
\hline & Planktothrix agardhii (Gom.) Anagn. et Kom. & 3.016 & 10.47 \\
\hline \multirow[t]{3}{*}{11.07 .01} & Planktothrix agardhii (Gom.) Anagn. et Kom. & 3.661 & 33.13 \\
\hline & Anabaena flos-aquae (Lyngb.) Breb. & 2.775 & 25.12 \\
\hline & Aphanizomenon flos-aquae (L.) Ralfs & 1.976 & 17.89 \\
\hline \multirow[t]{3}{*}{18.07 .01} & Planktothrix agardhii (Gom.) Anagn. et Kom. & 10.941 & 27.78 \\
\hline & Anabaena flos-aquae (Lyngb.) Breb. & 8.854 & 22.48 \\
\hline & Chlamydomonas sp. Ehr. & 5.674 & 14.41 \\
\hline \multirow[t]{3}{*}{25.07 .01} & Peridinium sp. Ehr. & 4.453 & 26.74 \\
\hline & Trachelomonas volvocina $\mathrm{Ehr}$. & 2.002 & 12.02 \\
\hline & Cyclotella sp. & 1.572 & 11.00 \\
\hline \multirow[t]{3}{*}{1.08 .01} & Cyclotella sp. & 5.418 & 23.26 \\
\hline & Peridinium sp. Ehr. & 4.020 & 17.26 \\
\hline & Anabaena flos-aquae (Lyngb.) Breb. & 3.266 & 14.01 \\
\hline \multirow[t]{3}{*}{8.08 .01} & Anabaena flos-aquae (Lyngb.) Breb. & 11.047 & 33.83 \\
\hline & Peridinium sp. Ehr. & 8.164 & 25.00 \\
\hline & Trachelomonas volvocina Ehr. & 5.453 & 16.70 \\
\hline \multirow[t]{4}{*}{15.08 .01} & Planktothrix agardhii (Gom.) Anagn. et Kom. & 8.005 & 34.36 \\
\hline & Anabaena flos-aquae (Lyngb.) Breb. & 3.808 & 16.35 \\
\hline & Euglena proxima Dang. & 1.500 & 6.44 \\
\hline & Trachelomonas volvocina Ehr. & 1.489 & 6.39 \\
\hline \multirow[t]{3}{*}{22.08 .01} & Anabaena flos-aquae (Lyngb.) Breb. & 12.130 & 45.77 \\
\hline & Trachelomonas volvocina Ehr. & 3.475 & 13.11 \\
\hline & Planktothrix agardhii (Gom.) Anagn. et Kom. & 3.336 & 12.59 \\
\hline \multirow[t]{3}{*}{29.08 .01} & Anabaena flos-aquae (Lyngb.) Breb. & 9.459 & 40.76 \\
\hline & Peridinium sp. Ehr. & 3.531 & 15.21 \\
\hline & Chlamydomonas sp. Ehr. & 2.737 & 11.79 \\
\hline \multirow[t]{3}{*}{5.09 .01} & Trachelomonas volvocina Ehr. & 11.690 & 45.23 \\
\hline & Planktothrix agardhii (Gom.) Anagn. et Kom. & 4.733 & 18.31 \\
\hline & Euglena proxima Dang. & 1.813 & 7.01 \\
\hline \multirow[t]{3}{*}{ 12.09.01 } & Trachelomonas volvocina Ehr. & 41.459 & 64.66 \\
\hline & Peridinium sp. Ehr. & 4.467 & 6.97 \\
\hline & Planktothrix agardhii (Gom.) Anagn. et Kom. & 3.879 & 6.05 \\
\hline 26.09 .01 & Planktothrix agardhii (Gom.) Anagn. et Kom. & 9.410 & 52.04 \\
\hline & Trachelomonas volvocina Ehr. & 1.607 & 8.89 \\
\hline & Euglena proxima Dang. & 1.108 & 6.13 \\
\hline
\end{tabular}




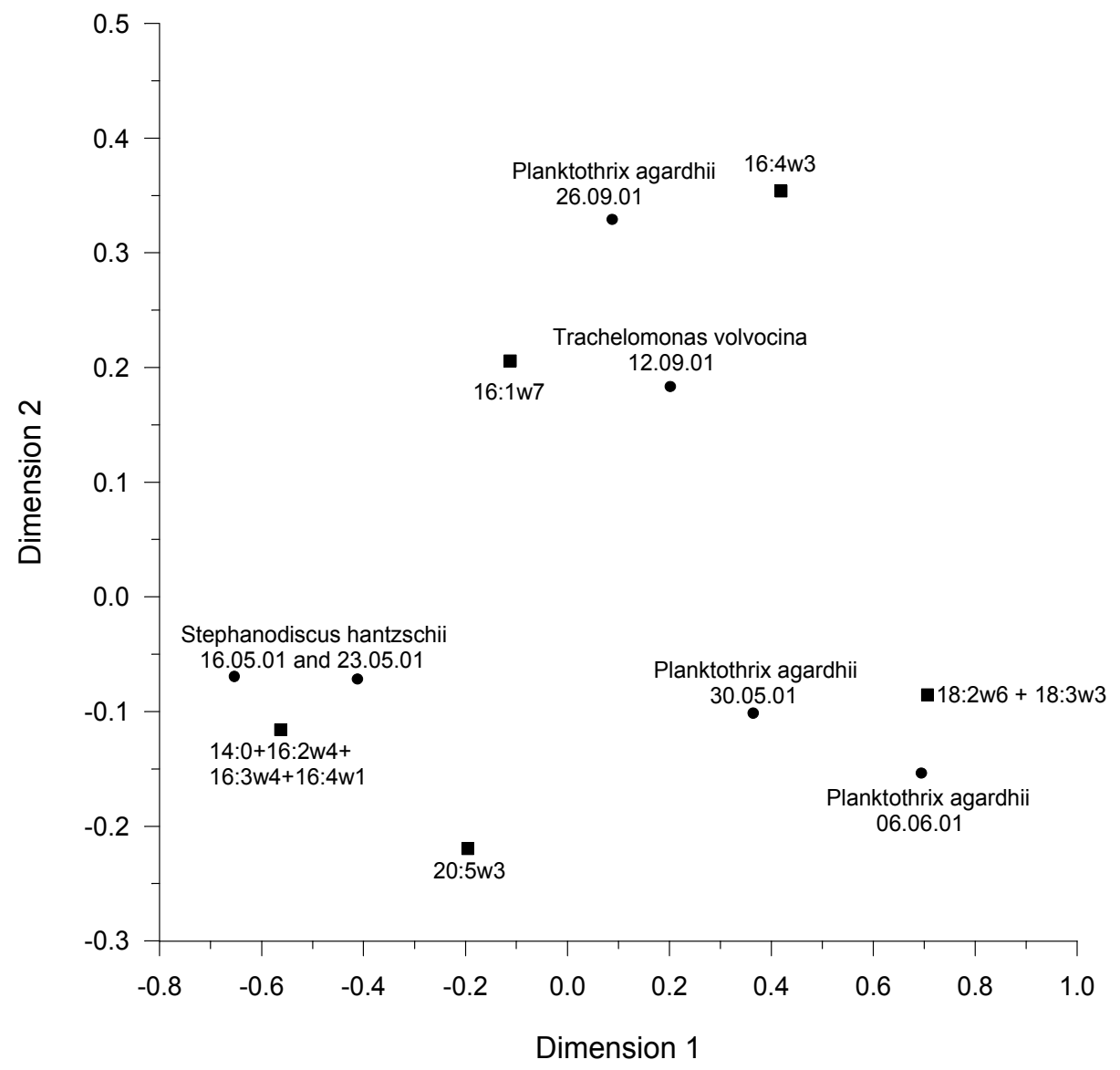

Fig. 4. Results of canonical analysis of correspondence of the FA-marker percentages in PL of seston (squares) on dates when some phytoplankton species (circles) were dominant (see text), May-September 2001, Bugach Reservoir, represented in a two-dimensional space reproduced $97.9 \%$ of total inertia

formed by two fatty acids: $18: 1 \omega 9$ and 18:2 $\omega 6$ (Fig.

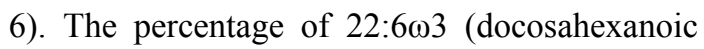
acid, DHA) showed a specific dynamic (Fig. 6, 7). This acid was contained in TAG of seston samples from the middle of May until the middle of June and from the middle of August to the end of the vegetation season. Marked percentages of DHA were found from the middle of May to the

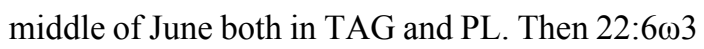
in PL appeared in seston at the end of July and in TAG - at the end of August (Fig. 7).

To reveal relation between FA groups of TAG on the one hand and particular species and groups of rotifers and ciliates on the other hand, the multivariate statistical analysis - CCA, was used. However, the results of the analysis were not statistically significant.

To determine spectra of nutrition of particular dominant species of micro- and mesozooplankton we carried out the canonical analysis of correspondence. We used in the analysis only those sampling dates when any species of rotifers or ciliates were strongly dominant, i.e. its biomass was $50 \%$ of total biomass of micro and mesozooplankton or higher. The percentage of FA-markers of cyanobacteria $(16: 3 \omega 3,16: 4 \omega 3$,

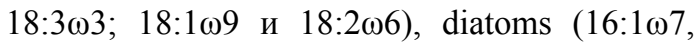

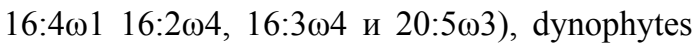

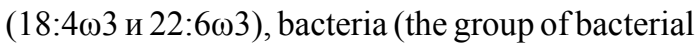

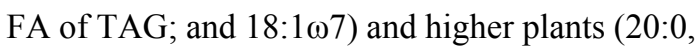



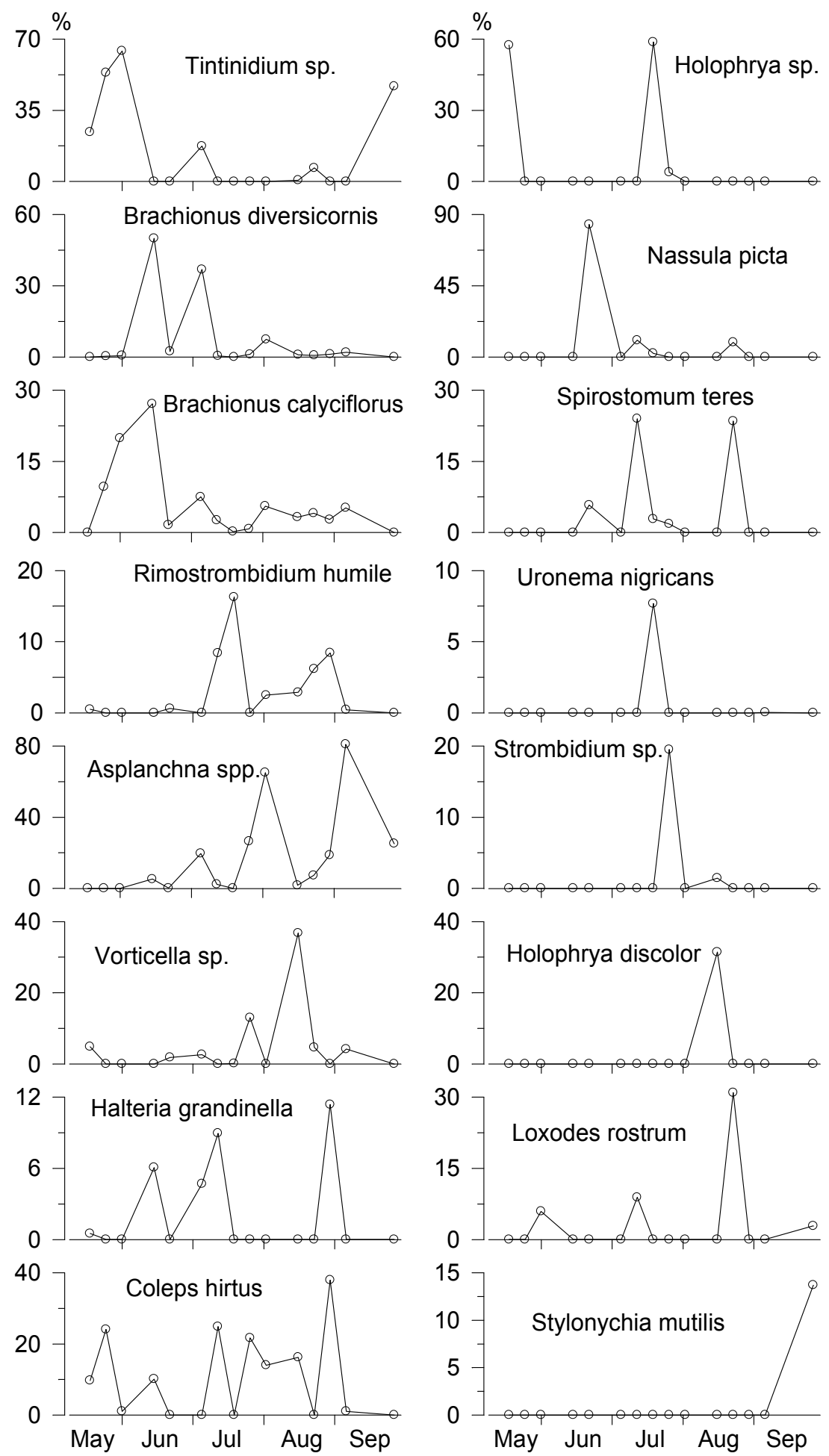

Fig. 5. Seasonal dynamics (\% of total biomass of micro- and mesozooplankton) of dominant species of protozoa and rotifers in Bugach Reservoir, 2001 


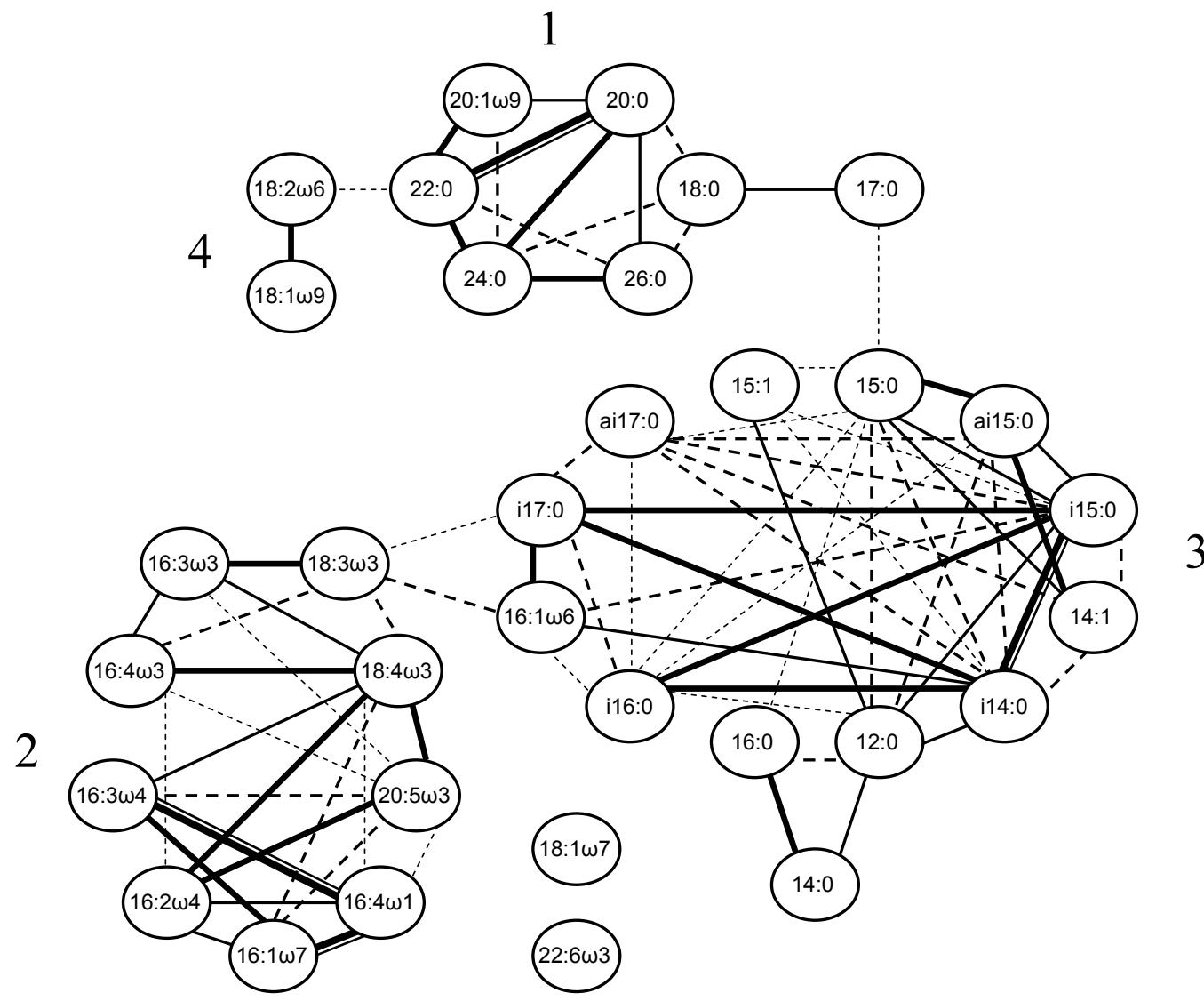

Fig. 6. Correlation graphs of fatty acids of TAG (\% of total) in seston of Bugach Reservoir, May-September 2001: $\mathrm{r}$ - statistically significant correlation coefficients $(\mathrm{p}<0.05) .1$-FA-markers of higher plants; 2 - FA-markers

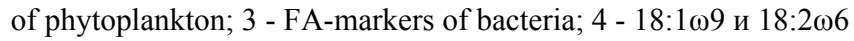

22:0, 24:0 and 26:0) in TAG of seston on sampling was represented in a two-dimensional space (Fig. 8). The fatty acids, which are markers for mentioned taxa, were chosen on basis of literature and our data (Erwin, 1973; Shaw, 1974; Claustre et al., 1988/1989; Ahlgren et al., 1992; Parrish et al., 1992; Cohen et al., 1995; Desvilettes et al., 1997; Leveille et al., 1997; Napolitano, 1999; Navarrete et al., 2000; Shin et al., 2000). In some cases, it is particularly difficult to differentiate between FA - markers of Cyanophyta and Chlorophyta. How-ever, cyanobacteria strongly dominated, while greens were not abundant in Bugach Reservoir in 2001. As previously found, fatty acids, i.e., 16:3 $13,16: 4 \omega 3,18: 3 \omega 3 ; 18: 1 \omega 9$ и 18:2 $\omega 6$, correlated with cyanobacteria in Bugach
Reservoir (Sushchik et al., 2003a, 2004), hence, they were used as markers of cyanobacteria here.

The first dimension explained $53 \%$ of inertia (of total Chi-square value) of the data set, and the second dimension reproduced $32.7 \%$. Chisquare values for both dimensions and the total Chisquare were significant $(\mathrm{P}<0.05)$. During the vegetation season several species of zooplankton con-stituted more then $50 \%$ ( $\%$ of total biomass): Holophrya sp. 16.05.2001 and 18.07.2001, Tinti-nidium sp. 23.05.2001 and 30.05.2001, N. picta 20.06.2001, and species of Asplanchna 01.08.2001 and 05.09.2001.

The first dimension (Fig. 8) demonstrated differences between four groups of species dominated in different seasonal periods: 1) Holophrya 

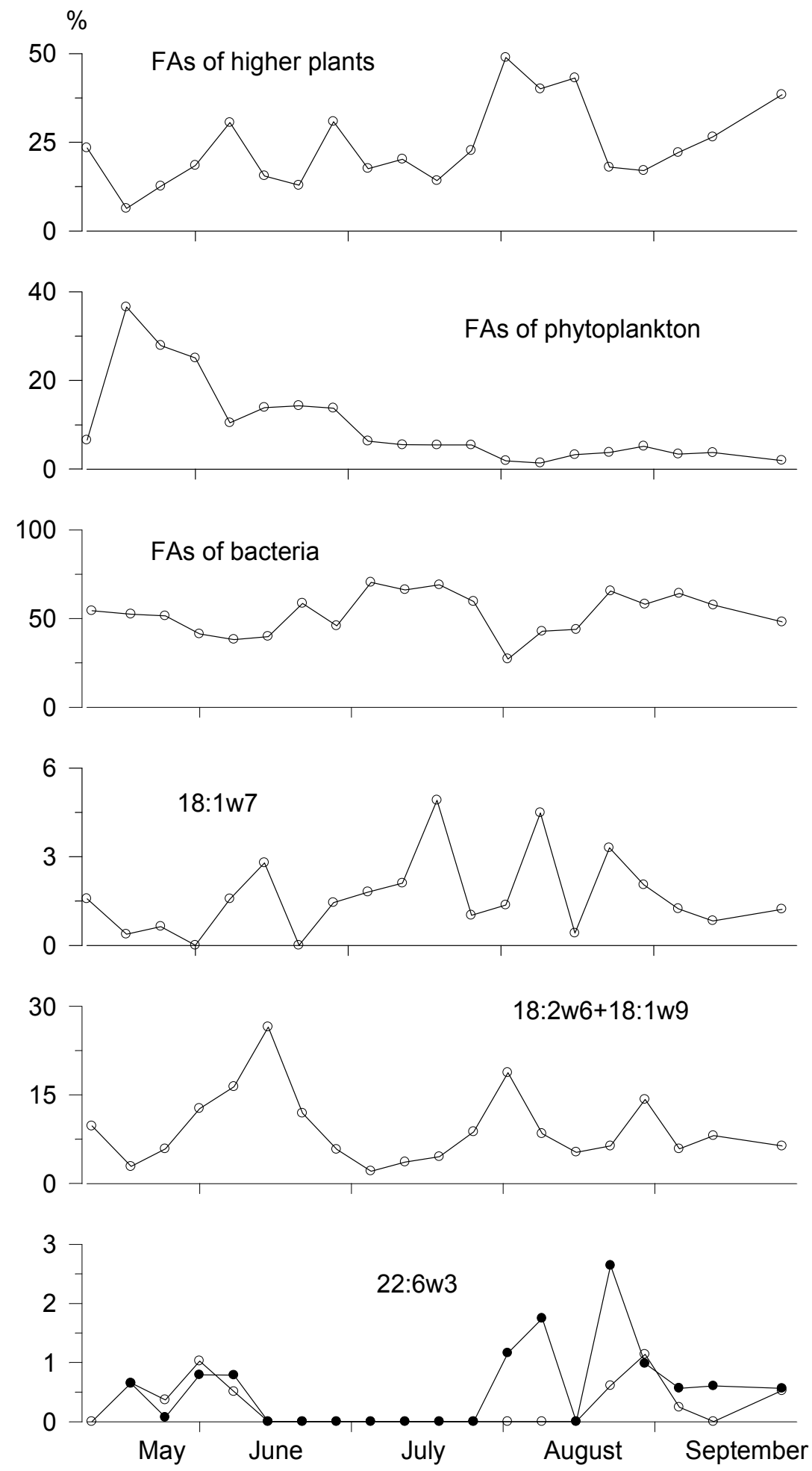

Fig. 7. Seasonal dynamics of FA groups and individual acids of TAG ( $\%$ of total) formed in the correlation graph (Figure 6), empty circles, and 22:6ஸ3 of PL, filled circles, in seston of Bugach Reservoir in 2001 


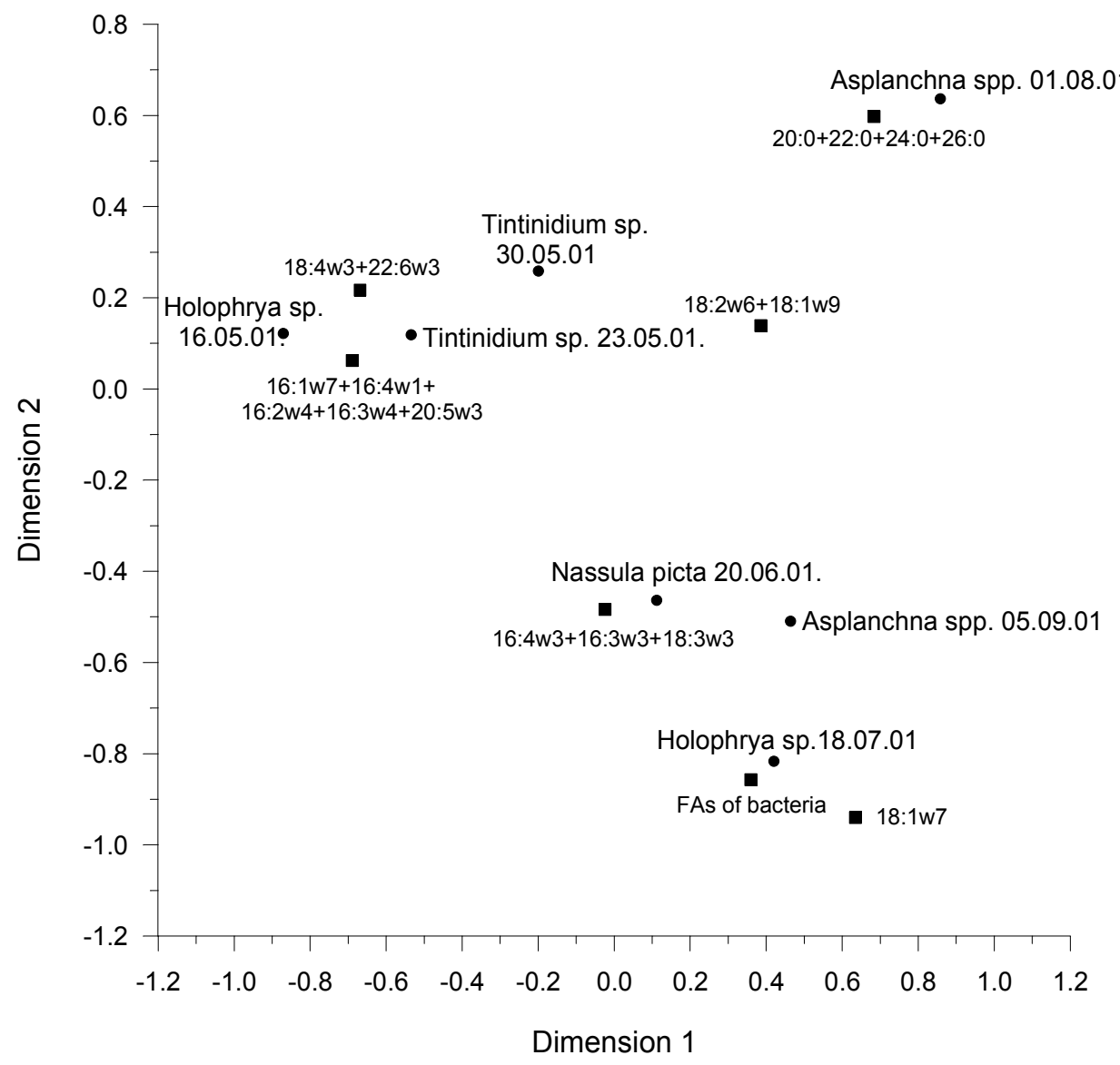

Fig. 8. Results of canonical correspondence analysis of the percentages of FA-markers of cyanobacteria, diatoms, dynophytes, bacteria and higher plants in TAG of seston (squares) on dates when some species microand mesozooplankton (circles) were dominant, May- September 2001, Bugach Reservoir, represented in a two-dimensional space reproduced $85.7 \%$ of total inertia

sp. 16.05.2001 and Tintinidium sp. 23.05.2001;

2) Tintinidium sp. 30.05 .2001 and N. picta 20.06.2001; 3) Holophrya sp. 18.07.2001 and species of Asplanchna 05.09.2001; 4) p. Asplanchna 01.08.2001. The differences in positions of zooplankton species in the first dimension were provided mostly by follow fatty acids: the first group was associated with FA-markers of diatoms and dynophytes; the second group was determined by FA-markers of cyanobacteria $(16: 3 \omega 3,16: 4 \omega 3$ and $18: 3 \omega 3)$; the third group was associated with FA-markers of bacteria and cyanobacteria which contain 18:1 $\omega 9$

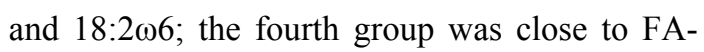

markers of higher plants and bacterial fatty acid

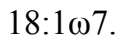

The second dimension indicated large differences between next groups: 1) species of $\mathrm{As}$ planchna 01.08.2001;2) Holophrya sp. 16.05.2001 and Tintinidium sp. 23.05.2001 and 30.05.2001; 3) N. picta 20.06.2001 and species of Asplanchna 05.09.2001; 4) Holophrya sp. 18.07.2001. These group positioning was provided by the differences between 1) FA-markers of higher plants; 2) FAmarkers of specific group of cyanobacteria

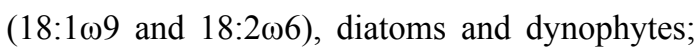
3) FA-markers of cyanobacteria $(16: 3 \omega 3,16: 4 \omega 3$, $18: 3 \omega 3)$; 4) bacterial fatty acids, respectively. 
We carried out the correlation analysis between fatty acids of PL and the same fatty acids of TAG. High coefficients of correlation were found for the acids which are not precursors for other FA in animal's tissues (iso- and anteiso fatty acids, $\omega 4, \omega 1$, and long chain saturated FA) (Table 2). These acids were included in TAG in its original form and were not desaturated further. When FA in PL and FA in TAG were correlated with a week shift, no any statistical significant correlation was revealed (Table 2). This was likely due to relatively high rate of metabolic processes in small organisms of rotifers and ciliates. Moreover, if changes in spectra of nutrition of

Table 2. Results of correlation analysis between the percentage of fatty acids of PL and the same acids of TAG in seston from Bugach Reservoir, 2001. Without a shift $(\mathrm{n}=19)$ and with a week shift $(\mathrm{n}=18)$. $*$ - $r>0.5$

\begin{tabular}{l|c|c}
\hline \multicolumn{1}{c}{ FA } & r & r a week shift \\
\hline $12: 0$ & 0.00 & -0.14 \\
$14: 0$ & 0.23 & 0.16 \\
$15: 0$ & 0.44 & 0.29 \\
$16: 0$ & 0.13 & 0.29 \\
i14:0 & $0.73^{*}$ & 0.43 \\
$14: 1$ & $0.76^{*}$ & 0.36 \\
i15:0 & $0.63^{*}$ & 0.44 \\
ai15:0 & $0.81^{*}$ & 0.24 \\
$15: 1$ & -0.14 & -0.32 \\
i16:0 & $0.62^{*}$ & 0.14 \\
i17:0 & -0.10 & -0.08 \\
ai17:0 & -0.13 & 0.06 \\
$16: 1 \omega 6$ & 0.01 & -0.27 \\
$18: 1 \omega 9$ & 0.21 & 0.03 \\
$18: 2 \omega 6$ & 0.07 & 0.18 \\
$16: 1 \omega 7$ & $0.59 *$ & 0.27 \\
$16: 2 \omega 4$ & 0.38 & 0.14 \\
$16: 3 \omega 4$ & $0.75^{*}$ & 0.28 \\
$16: 4 \omega 3$ & -0.05 & -0.03 \\
$16: 4 \omega 1$ & 0.16 & 0.41 \\
$16: 3 \omega 3$ & -0.24 & 0.07 \\
$18: 3 \omega 3$ & 0.32 & $0.54^{*}$ \\
$18: 4 \omega 3$ & -0.42 & -0.47 \\
$20: 5 \omega 3$ & 0.13 & 0.08 \\
$18: 0$ & 0.42 & -0.10 \\
$20: 0$ & $0.52^{*}$ & -0.06 \\
$20: 1 \omega 9$ & 0.05 & $0.58^{*}$ \\
$22: 0$ & 0.47 & 0.06 \\
$24: 0$ & 0.22 & -0.13 \\
$18: 1 \omega 7$ & -0.34 & 0.31 \\
$22: 6 \omega 3$ & 0.43 & 0.00 \\
\hline & &
\end{tabular}

animals were very quick, week might be too long period for revealing relationship between fatty acid composition of TAG in the animals and their potential food sources.

\section{Discussion}

As known, in eutrophic reservoirs where phytoplankton biomass is $>>0.8 \mathrm{mg} / \mathrm{L}$, the major part of organic matter of seston is provided by phytoplankton (Hessen et al., 2003; Gladyshev et al., 2007). Consequently, most FA of polar lipids originate from phytoplankton. The main part of FA whish are markers of different alga taxa were joined into one large group in the correlation graph for PL. Perhaps, this resulted from the fact that different alga taxa with different fatty acid markers coexisted together in the plankton community at the same time (Table 1). FA markers of Bacillariophyta and bacteria combined into one group because diatoms and bacteria had similar seasonal dynamics of biomass. Besides phytoplankton and bacteria, there were FA markers of aquatic higher plants and allochthonous organic matter (i.e., terrestrial higher plants) in PL.

We suppose that there were three groups of bacterioplankton which were the sources of 18:107 and ai17:0 and bacterial fatty acids of group 3 in the correlation graph for TAG. To reveal sources of bacterial fatty acids we compared seasonal dynamics of 18:1 107 , ai17:0 and bacterial fatty acids of group 3 and of uncultivated (natural) bacterioplankton (Trusova and Gladyshev, 2005). The source of 18:107 was likely the clone sp 34, the sources of bacterial fatty acids of group 3 might be the clones sp 24, 31, 32, 35, 36 and 39 . The sources of ai17:0 were not detected among presented clones.

The canonical correspondence analysis allows us to define FA - markers of particular algae species. We found that typical FA-markers for Stephanodiscus sp. population in Bugach Reservoir

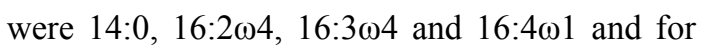




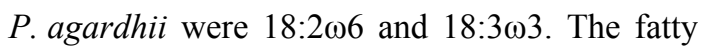
acids $16: 1 \omega 7$ and 20:5 $\omega 3$ are currently considered as markers of diatoms (Claustre et al., 1988/1989; Parrish et al., 1992; Leveille et al., 1997; Shin et al., 2000). These two acids separated from diatom FA-markers and were close to the second group of algae (P. agardhii 30.05.2001 and 26.09.2001 and $T$. volvocina 12.09.2001) in the first dimension of canonical analysis. However, Stephanodiscus sp. was found in large quantities at 30.05.2001. Hence, this confirms our consideration of 16:1 107 and 20:5 13 as primary markers of Stephanodiscus sp. in Bugach Reservoir.

As a rule, fatty acid $16: 403$ is characteristic for species of Chlorophyta and Euglenophyta (e.g., Erwin, 1973; Desvilettes et al., 1997; McLachlan et al., 1999). Consequently, the sample of phytoplankton taken and 12.09.2001 (dominant taxa was $T$. volvocina) and fatty acid 16:4ఱ3 formed the joint group, athough the sample of 26.09.2001 (dominant taxa was P. agardhii) was also present in this group. However, it could be due to high abundance of both $T$. volvocina and Euglena proxima Dang. (Euglenophyta) in seston 26.09.2001 (Table 1). Hence, FA 16:4ఱ3 was likely a marker of $T$. volvocina inhabited Bugach Reservoir.

We compared FA groups in correlation graphs of PL and TAG. FA-markers of bacteria and diatoms joined in the combined group in polar lipids but these fatty acids were separated into different groups in TAG. Such fatty acid positions in the studied lipid classes likely indicate that diatoms and bacteria were consumed by protozoa and rotifers selectively.

On basis of dynamics of the main FA groups in sestonic TAG we can elucidate patterns of seasonal micro- and mesozooplankton nutrition. The consumption of bacteria by protozoa and rotifers was relatively even during all vegetation season (Fig. 7). The consumption of detritus originated from higher plants was the highest at the beginning of August. Phytoplankton was more intensively consumed in spring during active growth of diatoms (Stephanodiscus sp.) and from the middle to the end of June when cyanobacteria, dynophytes, euglenas and diatoms (A. flosaquae, Aph. flos-aquae, P. agardhii, Peridinium sp., E. proxima and Stephanodiscus sp.) were dominated in Bugach Reservoir. Some species of cyanobacteria were consumed in the middle of June, at the beginning and the end of August (Fig. 7). The analysis of seasonal dynamics of FA marker groups in TAG and PL is described in detail elsewhere (Makhutova et al., 2004).

It should be noted that fatty acid 22:6 13 was included in group 2 in PL. Meanwhile, seasonal dynamics of this acid in TAG differed from other fatty acids. As known, the main source of 22:6 13 in freshwaters is dynophytes (Ahlgren et al., 1992, 1997; Desvilettes et al., 1997). However, dynophytes were absent in the Reservoir in may and early June, whereas DHA percentages were relatively large. We suppose that DHA in PL and TAG in this period was likely the result of $d e$ novo synthesis by micro- and mesozooplankton from 20:5 33 synthesized by diatoms. Peridinium sp. which synthesizes 22:603 in large quantities dominated in Bugach Reservoir from the end of July. Consequently, protozoa and rotifers were feeding on Peridinium sp. from the middle of August to the end of vegetation season (Fig. 7).

It is interesting that FA of TAG and FA of PL in correlating graphs formed different groups (Fig. 2, 6). These differences may due to of several probable reasons. Firstly, they may be attributed to changes in nutrition of some dominant groups of rotifers or ciliates during the vegetation season. In this case, such group of micro- and mesozooplankton had to dominate strongly in the Reservoir during long period of time. The only species, C. hirtus was observed for a long time in water co-umn but its biomass wasn't very high and was reached the maximum value of $40 \%$ (of 
total biomass of micro- and mesozooplankton). Secondly, these differences may also result from temporal succession of dominant species of microand mesozooplankton with different spectrum of nutrition.

Evidently, there might be the selectively feeding species of micro- and mesozooplankton which observed in water column only for limited periods and those inhabited the water column for a longer time. The dominant species of microand mesozooplankton changed each other during the studied period in Bugach Reservoir (Fig. 5). Besides, the seasonal dynamics of FA of TAG (Fig. 7) were characterized by short-term peaks that may reflect frequent and quick succession of dominant species of micro- and mesozooplankton. Consequently, the change of dominant species with different nutrition spectra was more typical pattern for Bugach Reservoir than presence few dominant species with variable feeding during the vegetation season.

On the basis of the canonical analysis of correspondence we conclude about nutrition spectra of dominant species of microzooplankton. Tintinidium sp. and Holophrya sp. were joined into one group in both dimensions due to FA-markers of diatoms and dynophytes, although, dynophytes were absent in Bugach Reservoir in spring. Probably, Tintinidium sp. and Holophrya sp. synthe-sized 18:4 $\omega 3$ (by means of retroconversion)

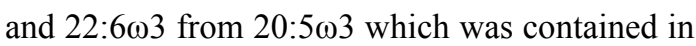
the diatom Stephanodiscus sp. in spring. Thus, protozoa Tintinidium sp. and Holophrya sp. Likely fed on diatoms in May. Spectrum of nutrition of Holophrya sp. evedently changed during the season according to the canonical analysis of correspondence. This protozoan consumed diatoms in spring and bacteria in the middle of July. N. picta fed on cyanobacteria in June. The spectrum of nutrition of Asplanchna spp. was also variable during the season. The species likely consumed bacteria, cyanobacteria, and detritus of higher plants. However, the most of species of Asplanchna genera including A. girodi and A. brightwelli which were observed in Bugach Reservoir are known as predators (Krylov, 1989, Lazareva, 2004). We suppose that these rotifers could consume some species of microzooplankton which fed on bacteria, cyanobacteria and detritus. Similar phenomenon of FA transfer from bacteria to ciliates and further to predatory copepods has been previously described (Ederington et al., 1995). Unfortunately, we failed to determine the exact spectrum of nutrition of Asplanchna spp. using FA-markers.

\section{Conclusions}

Fatty acid-markers of dominant species of algae from Bugach Reservoir were specified. The correlation groups of FA differed between PL and TAG fractions in composition and seasonal dynamics. The differences were likely due to the succession of species of micro- and mesozooplankton with different spectra of nutrition and changes in nutrition of one or some dominant zooplankton species during the vegetation season in a less extent.

The spectra of nutrition of dominant species of protozoa from Bugach Reservoir were estimated on the base of FA-markers of TAG in seston. Holophrya sp. consumed diatoms in spring and bacteria in the middle of the summer. Species N. picta fed on cyanobacteria and Tintinidium sp. fed on diatoms and cyanobacteria.

\section{Acknowledgements}

We used GS-MS of Joint Equipment Unit of Krasnoyarsk Scientific Centre of Siberian Branch of Russian Academy of Sciences. The work was supported by award No. REC-002 of the Ministry of Education and Sciences of Russian Federation and U.S. Civilian Research \& Development Founda-tion for the Independent States of the Former Soviet Union (CRDF), a grant of Russian 
Foundation for Basic Research (RFBR) No. 05-0448423, 07-04-96825, 07-05-00076. At the stage of generali-sation the work was also supported by a personal grant from the Russian Science Support Founda-tion.

\section{References}

Ahlgren G., Goedkoop W., Markensten H., Sonesten L., Boberg M. (1997) Seasonal variations in food quality for pelagic and benthic invertebrates in lake Erken - the role of fatty acids. Freshwater Biol.38: 555-570.

Ahlgren G., Gustafsson I.-B., Boberg M. (1992) Fatty acid content and chemical composition of freshwater microalgae. J. Phycol. 28: 37-50.

Balushkina, E.V., Winberg, G.G. (1979) Relation between mass and body size of plankton animals. In Winberg (ed.), General backgrounds for study of aquatic ecosystems. Nauka, Leningrad, pp. 169-172. (in Russian)

Bern L. (1990) Size-related discrimination of nutritive and inert particles by freshwater zooplankton. J. Plankton Res. 12 (5): 1059-1067.

Bligh, E.G., Dyer, W. (1959) A rapid method of total lipid extraction and purification. Canadian Journal of Biochemistry and Physiology 37: 911-917.

Bourdier G.A., Amblard C.A. (1989) Lipids in Acanthodiaptomus denticornis during starvation and fed on three different algae. J. Plankton Res. 11: 1201-1212.

Brown M.R., Dustan G.A., Norwood S.R., Miller K.A. (1996) Effect of harvest stage and light on the biocamical composition of the diatom Thalassiosira pseudomona. J. Phycol. 32: 64-73.

Claustre H., Marty J.-C., Cassiani L., Dagaut J. (1988/1989) Fatty acid dynamics in phytoplankton and microzooplankton communities during a spring bloom in the coastal Ligurian Sea: ecological implications. Mar. Micr. Food Webs 3 (2): 51-66.

Cobelas A., Lechado Z. (1989) Lipids in microalgae. A review 1. Biochemistry Grasas y aceites (Esp). 40 (2): 118-145.

Cohen Z., Margheri M.C., Tomaselli L. (1995) Chemotaxonomy of cyanobacteria. Phytochemistry, 40 (4): 1155-1158.

DeMott W.R. (1986) The role of taste in food selection by freshwater zooplankton. Oecologia 69: 334-340.

DeMott W.R. (1995) The influence of prey hardness on Daphnia's selectivity for large prey. Hydrobiologia 307: 127-138.

Desvilettes C., Bourdier G., Amblard C., Barth B. (1997) Use of fatty acids for the assessment of zooplankton grazing on bacteria. protozoans and microalgae. Freshwater Biol. 38: 629-637.

Ederington M.C., McManus G.M., Harvey H.R. (1995) Trophic transfer of fatty acids, sterols and a triterpenoid alcohol between a bacteria, a ciliate and the copepod Acartia tonsa. Limnol. Oceanogr. 40 (5): $860-867$.

Erwin J. (1973) Comparative biochemistry of fatty acids in eucaryotic microorganisms. Lipids and biomembranes of eucaryotic microorganisms, Academic Press, NewYork, p. 41-143. 
Foissner W., Berger H. (1996) A user-friendly guide to the ciliates (Protozoa, Ciliophore) commonly used by hydrobiologists as bioindicatators in rivers, lakes, and waste waters, with notes on their ecology. Freshwater Biol. 35: 375-482.

Gladyshev M. I., Sushchik N. N., Skoptsova G. N., Parfentsova L. S., Kalacheva G. S. (1999) Use of Biochemical Markers Provides Evidence of Selective Feeding in Zoobenthic Omnivorous Organisms of a Fish-rearing Pond. Doklady Biological Sciences 364 (1): 67-69.

Gladyshev M.I., Emelianova A.Y., Kalachova G.S., Zotina T.A., Gaevsky N.A., Zhilenkov M.D. (2000) Gut content analysis of Gammarus lacustris from a Siberian lake using biochemical and biophysical methods. Hydrobiologia 431: 155-163.

Gladyshev M.I., Gribovskaya Y.V., Moskvichova A.V., Muchkina E.Y., Chuprov S.M., Ivanova E.A. (2001) Content of metals in compartments of ecosystem of a Siberian pond. Arch. Environ. Contam. Toxicol. 41: 157-162.

Gladyshev M.I., Sushchik N. N., Kolmakova A.A., Kalachova G.S., Kravchuk E.S., Ivanova E.A., Makhutova O.N. (2007) Seasonal correlations of elemental and $\omega 3$ PUFA composition of seston and dominant phytoplankton species in a eutrophic Siberian Reservoir. Aquatic Ecology 41: 9-23

Gutelmakher B. L. (1986) Metabolism of plankton as a single whole: Trophometabolical interactions between zoo- and phytoplankton. Nauka, Leningrad, 155 p. (in Russian)

Hessen D.O., Andersen T., Brettum P., Faafeng B.A. (2003) Phytoplankton contribution to sestonic mass and elemental ratios in lakes: Implications for zooplankton nutrition. Limnol. Oceanogr. 48: 12891296.

Joaquim-Justo C., Detry C., Caufman F., Thome J.-P. (2004) Feeding of planktonic rotifers on ciliates: a method using natural ciliate assemblages labeled with fluorescent microparticles. J. Plankton Res. 26 (2): 1289-1299.

Jeffers J. (1981) An Introduction to System Analysis: with Ecological Application. Mir, Moscow (translated from English).

Kalachova G.S., Zhila N.O., Volova T.G. (2001) Lipids of the green algae Botryococcus during stage growth in batch culture. Mikrobiologiya 70: 305-312.

Krylov P. I. (1989) Nutrition of freshwater predatory zooplankton. Itogi nauki i tehniki, VINITI, series: General ecology. Biocenology. Hydrobiology. V.7, p. 1-148. (in Russian)

Lazareva V. I. (2004) Seasonal life-cycle and feeding of predatory rotifer of genus Asplanchna in the Rybinsk reservoir. Biology of Inland Waters. N4: 59-68. (in Russian)

Leveille J.C., Amblard C., Bourdier G. (1997) Fatty acids as specific algal markers in a natural lacustrian phytoplankton. J. Plankton Res. 19 (4): 469-490.

Makhutova O.N., Kalachova G.S., Gladyshev M.I. (2003) A comparison of the fatty acid composition of Gammarus lacustris and its food sources from a freshwater reservoir, Bugach, and the saline Lake Shira in Siberia, Russia. Aquatic Ecology 37: 159-167

Makhutova O.N., Sushchik N.N., Kalacheva G.S. (2004) The information value of fatty acid composition of triacylglycerols and polar lipids of seston in assaying the food spectrum of microzooplankton in the Bugach Reservoir. Doklady Biological Sciences 395: 143-145.

McLachlan J.L., Curtis J.M., Boutilier K., Keusgen M., Seguel M.R. (1999) Tetreutreptia pomquetensis (Euglenophyta), a psychrophilic species: growth and fatty acid composition. J. Phycol. 35: 280-286. 
Napolitano G.E., Ackman R.G. (1989) Lipids and hydrocarbons in Corophium volutator from Minas Basin. Nova Scotia. Marine Biol. 100 (3): 333-338.

Napolitano G.E. (1999) Fatty acids as trophic and chemical markers in freshwater ecosystems In: Arts M.T., Wainman B.C. (ed.) Lipids in freshwater ecosystems, Springer-Verlag, New York, p. 21-44.

Navarrete A., Peacock A., Macnaughton S.J., Urmeneta J., Mas-Castella J., White D.C., Guerrero R. (2000) Physiological status and community composition of microbial mats of Ebro delta, Spain, by signature lipids. Microbiol. Ecol. 39: 92-99.

Olsen Y. (1999) Lipids and essential fatty acids in aquatic food webs: what can freshwater ecologists learn from mariculture? In: Arts M.T., Wainman B.C. (ed.) Lipids in Freshwater Ecosystems, SpringerVerlag, New York, p.161-202.

Ooms-wilms A.L. Postema G., Gulati R.D. (1999) Population dynamics of planktonic rotifers in lake Loosdrecht, the Netherlands, in relation to their potential food and predators. Freshwater Biol. 42: 77-97.

Parrish C.C., Bodennec G., Macpherson E.J., Ackman R.G. (1992) Seawater fatty acids and lipid classes in an Urban and a Rural Nova Scotia inlet. Lipids. 27 (8): 651-655.

Porter K.G. (1975) Viable gut passage of gelatinous green algae ingested by Daphnia. Verh. Intern. Ver. theor. angew. Limnol. 19 (4): 2840-2850.

Scherwass A. Fischer Y., Arndt H. (2005) Detritus as a potential food source for protozoans: utilization of fine particulate plant detritus by a heterotrophic flagellate, Chilomonas paramecium, and a ciliate, Tetrahymena pyriformis. Aquatic Ecology. 39: 439-445.

Shaw N. (1974) Lipid composition as a guide to the classification of bacteria. Advances in Applied Microbiology, (Portmann D., ed.). Acad. Press, London, New York: 17, p. 63-108.

Shin K.H., Hama T., Yoshie N., Noriki S., Tsunogai S. (2000) Dynamics of fatty acids in newly biosynthesized phytoplancton cells and seston during a spring bloom off the west coast of Hokkaido Island, Japan. Marine Chem. 70: 243-256.

Sushchik N.N., Gladyshev M.I., Kalachova G.S., Kravchuk E.S., Dubovskaya O.P., Ivanova E.A. (2003a) Particulate fatty acids in two small Siberian reservoirs dominated by different groups of phytoplankton. Freshwater Biol. 48: 394-403.

Sushchik N.N., Gladyshev M.I., Makhutova O.N., Kalachova G.S., Kravchuk E.S., Ivanova E.A. (2004) Associating particulate essential fatty acids of the $\omega 3$ family with phytoplankton species composition in a Siberian reservoir. Freshwater Biol. 49: 1206-1219.

Sushchik N.N., Gladyshev M.I., Moskvicheva A.V., Makhutova O.N., Kalachova G.S. (2003b) Comparison of fatty acid composition in major lipid classes of the dominant benthic invertebrates of the Yenisei river. Compar. Biochem., Physiol. Part B. 134: 111-122.

Thouvenot A., Debroas D., Richardot M., Devaux J. (1999) Impact of natural metazooplankton assemblage on planktonic microbial communities in a newly flooded reservoir. J. Plankton Res. 21 (1): 179-199.

Tonon T., Harvey D., Larson T.R., Graham I.A. (2002) Long chain polyunsaturated fatty acid production and partitioning to triacylglycerols in four microalgae. Phytochemistry 61: 15-24. 
Trusova M.Yu., Gladyshev M.I. (2005) Species Composition of Winter Bacterioplankton in Blooming and Nonblooming Reservoirs as Determined by 16S rRNA Sequences. Doklady Biological Sciences. 405: 443-444.

Vrede T., Vrede K. (2005) Contrasting "top-down" effects of crustacean zooplankton grazing on bacteria and phytoflagellates. Aquatic Ecology. 39: 283-293. 